\title{
Risk Management Behaviors of High School Principals in the Supervision of Their High School Physical Education and Athletic Programs
}

\author{
Gary R. Gray \\ Montana State University - Billings \\ Billings, Montana
}

\section{INTRODUCTION}

It seems that a high school principal is responsible for everything. A Minnesota court held that the principal of the high school in which a student suffered severe injuries in a physical education class was negligent for failing to perform his duty to exercise reasonable care in supervising the development, planning, and administration of the physical education curriculum (Larson v. Independent School District No. 314, 289 N.W. 2d 112). Likewise in an athletic case, a Michigan court stated that a high school principal had a duty to exercise reasonable supervisory powers so as to minimize the likelihood of injuries to students (Vargo v. Svitchan, 301 N. W. 2d 1). Indeed, much of the professional literature concerning school principals has described the principals' legal and professional responsibility to provide reasonable administrative supervision of school programs (Essex, 1986; Gluckman, 1985; Hager \& Scarr, 1983; Hansen \& Smith, 1989; Heitman, 1988; Hill, 1990; Kienapfel, 1984; Virgilio \& Virgilio, 1989; Zirkel \& Moore, 1986).

Even though the principal of a school might not be in direct, daily contact with every program and every activity within the school and even though the principal cannot be expected to be an expert in every curricular area represented within the school, the principal, as chief building administrator, has the ultimate authority and responsibility for each activity and program offered by the school. Part of this responsibility requires that the principal supervises the high school curricular and extracurricular programs in a reasonable manner. With physical education and athletics, this administrative supervision process involves two major components: (1) determining that the physical education curriculum and athletic program are planned and developed to be reasonably safe, and (2) determining that the physical education curriculum and athletic program are implemented in a reasonably safe manner. Of course, each of these two components can involve several specific administrative actions. 


\section{Planning and Developing a Reasonably Safe Physical Education and Athletic Program}

The curriculum development process can occur in many ways. The high school might be part of a school district large enough to have one or several curriculum development specialists who oversee the development of the various curricula. For example, the school district might have a K-12 health and physical education curriculum that has been developed by health and physical education teachers from the various schools in the district who served as a curriculum committee during portions of one or more summers. The curriculum development specialist might have served as a facilitator for the committee members who were chosen because of their expertise in health and physical education. In this role, the curriculum development specialist was able to lead the teachers through the curriculum development process selected by the school district. Each curricular area might have a K-12 curriculum following approximately the same format to give the district's various curricula some consistency. Following initial development, the district probably identified a systematic rotation of curriculum revision on a five or six year cycle.

Smaller school districts typically do not enjoy the convenience of having as many district curriculum specialists. One person might oversee the development and revision of all curricula. A small district, with perhaps only a few or even only one school in some rural districts, might have no curriculum specialists at all. In this case, the local school district might have hired a consultant to lead the teachers through the curriculum development process in physical education. Or, in other situations, the teachers might simply have taken the initiative to develop a curriculum, in accordance with state guidelines, so that their students would have high quality physical education. In any event, it is the principal as the building administrator who must see that students do have a sound educational experience with the various curricula. The principal must determine that, at least for his or her building, a sound curriculum exists. For physical education, the curriculum must be not only educationally sound but also reasonably safe. The same is true for the development of the interscholastic program in athletics.

\section{Supervising the Implementation of Physical Education and Athletic Programs}

The most well-planned physical education curricula and athletic programs accomplish nothing unless they are implemented properly. Within any particular high school, the administrative responsibility of determining that this occurs falls to the building principal. Of course, in larger schools there might be a physical education department head, and there is almost certainly an athletic director; however, the single person charged with the responsibility of overseeing each of these areas, as well as all other programs and activities in the school, is the high school principal.

The principal might decide to use various strategies to facilitate this administrative responsibility. The principal might require that all physical education teachers submit lesson plans on a weekly basis and unit plans on a quarterly basis to determine that appropriate instruction is occurring within the curriculum. He or 
she might require coaches to submit practice plans on a regular basis. Additionally, the principal might schedule a series of observations during which physical educators and coaches can be observed working with the students. These observations might occur as part of a systematic process of teacher and coach evaluation. Other individuals with administrative responsibilities, including a physical education department head and an athletic director, should also be involved in the program and staff supervision process; however, even if the principal delegates part of this supervision, the principal is still obligated to determine that appropriate administrative supervision occurs. It was, therefore, the purpose of this study to determine the degree to which high school principals indicated that they performed various risk management behaviors related to supervision of their physical education and athletic programs.

\section{METHODOLOGY}

Data were collected by mailing a survey to all 445 high school principals in the state of Iowa. The survey, developed by the investigator, consisted of 20 items addressing risk management behaviors related to principal supervision of high school physical education programs, 20 items addressing risk management behaviors related to principal supervision of high school athletic programs, and various demographic items. Subjects responded to the 40 risk management behavior items by indicating the degree to which they performed the specific behaviors identified in each of the 40 survey items by using the following Likert-type scale of consistency: 5=Always, $4=$ Often, $3=$ Sometimes, $2=$ Seldom, and $1=$ Never. The rationale for using a scale of consistency was based upon the idea that supervisors of sport-related programs can decrease the likelihood of participant injuries and possible lawsuits by consistently performing various risk management behaviors in an effort to prevent unreasonable injuries. Lower levels of consistency would seem to increase the likelihood of injury to participants.

Subjects received the survey, a cover letter describing the study and explaining how to complete the survey, and a postage paid, self-addressed, return envelope. Subjects who had not returned their completed surveys three weeks following the original mailing were sent another survey, a cover letter, and a postage paid, selfaddressed, return envelope. All responses by subjects were anonymous. Completed surveys were received from 280 high school principals in the state of Iowa for a return rate of $62.9 \%$.

\section{RESULTS AND DISCUSSION}

Table 1 shows the relevant demographic data for the high school principals who participated in this study $(\mathrm{N}=280)$. 
Table 1. Demographic Data on Subjects $(N=280)$.

\begin{tabular}{|c|c|c|c|}
\hline Gender & $\begin{array}{l}\text { Men } \\
\text { Women } \\
\text { No data }\end{array}$ & $\begin{array}{l}=264 \\
=12 \\
=\quad 4\end{array}$ & \\
\hline Age & $\begin{array}{l}\text { Mean } \\
\text { S.D. }\end{array}$ & $\begin{array}{l}=46 \\
=8\end{array}$ & $\begin{array}{l}.281 \text { years } \\
.546\end{array}$ \\
\hline Education (highest degree earned) & $\begin{array}{l}\text { Bachelors } \\
\text { Masters } \\
\text { Doctorate } \\
\text { Other } \\
\text { No data }\end{array}$ & $\begin{array}{l}=3 \\
=213 \\
=24 \\
=36 \\
=4\end{array}$ & \\
\hline Years as principal & $\begin{array}{l}\text { Mean } \\
\text { S.D. }\end{array}$ & $\begin{array}{l}=11 \\
=8\end{array}$ & $\begin{array}{l}.822 \text { years } \\
.889\end{array}$ \\
\hline Years as principal in present school & $\begin{array}{l}\text { Mean } \\
\text { S.D. }\end{array}$ & $\begin{array}{l}=8 \\
=7\end{array}$ & $\begin{array}{l}.402 \text { years } \\
.441\end{array}$ \\
\hline Physical education teaching background & $\begin{array}{l}\text { Yes } \\
\text { Presently } \\
\text { Previously } \\
\text { No } \\
\text { No data }\end{array}$ & $\begin{array}{l}=4 \\
=129 \\
=142 \\
=5\end{array}$ & \\
\hline Athletic director background & $\begin{array}{l}\text { Yes } \\
\text { Presently } \\
\text { Previously } \\
\text { No } \\
\text { Missing data }\end{array}$ & $\begin{array}{l}=41 \\
=130 \\
=106 \\
=3\end{array}$ & \\
\hline Coaching background & $\begin{array}{l}\text { Yes } \\
\text { Presently } \\
\text { Previously } \\
\text { No } \\
\text { No data }\end{array}$ & $\begin{array}{l}=20 \\
=211 \\
=44 \\
=5\end{array}$ & \\
\hline Number of students in high school & $\begin{array}{l}\text { Mean } \\
\text { S.D. }\end{array}$ & $\begin{array}{l}=407 \\
=363\end{array}$ & $\begin{array}{l}.409 \\
.264\end{array}$ \\
\hline Football classification & $\begin{array}{l}\text { A } \\
1 A \\
2 A \\
3 A \\
4 A \\
\text { No football } \\
\text { No athletics } \\
\text { No data } \\
\text { Total }\end{array}$ & $\begin{array}{l}=69 \\
=72 \\
=48 \\
=52 \\
=27 \\
=5 \\
=1 \\
=6 \\
=280\end{array}$ & (smallest schools) \\
\hline
\end{tabular}


Table 2 shows the data related to the physical education and athletics lawsuits which had occurred in the subjects' high schools during the time when the subjects had been principals of their schools.

Table 2. Lawsuit History of Subjects $(N=280)$.

$\begin{array}{ll}\begin{array}{ll}\text { Has your school district been sued for a sport-related injury } \\ \text { at your school since you have been principal? }\end{array} & \text { Yes } \\ & \text { No }=32 \\ & \text { No data }=6\end{array}$

Table 3 shows the ranked means and corresponding standard deviations for the self-reported risk management behaviors related to the subjects' physical education curriculum supervision practices. According to the data in Table 3, the high school principals rated themselves rather well, considering that 12 of the 20 physical education items had means exceeding 4.0 on the 5-point scale. In fact, only 4 of the 20 physical items had means lower than 3.5 .

Table 3. Aanked Means of Principals' Risk Management Behaviors Related to Supervision of the Physical Education Curriculum.

\begin{tabular}{llrr}
\hline Rank & Risk Management Behavior & Mean & S.D. \\
\cline { 3 - 4 } 2 & Evaluates physical education teachers & 4.776 & .532 \\
2 & Title IX requirements met in physical education & 4.686 & .625 \\
3 & Adequate supervision in physical education class & 4.603 & .743 \\
4 & Physical education teachers qualified in areas taught & 4.572 & .811 \\
5 & New teachers informed of responsibilities & 4.504 & .809 \\
6 & Written curriculum guide in physical education & 4.413 & .944 \\
7 & Medical emergency procedures exist & 4.317 & 1.041 \\
8 & Facilities maintained acceptably & 4.281 & .797 \\
9 & Physical education based on sound educational objectives & 4.245 & .814 \\
10 & New physical education teachers supervised closely & 4.207 & .899 \\
11 & Adequate safety measures exist in physical education & 4.104 & .923 \\
12 & Sound methodology in physical education instruction & 4.036 & .840 \\
13 & Written grading procedures exist in physical education & 3.935 & 1.376 \\
14 & Written unit plans required in physical education & 3.903 & .341 \\
15 & Objective grading criteria required in physical education & 3.762 & 1.183 \\
16 & Written lesson plans required in physical education & 3.723 & 1.562 \\
17 & Sufficient physical education instruction provided & 3.493 & .254 \\
18 & Involvement in physical education curriculum design process & 3.342 & 1.052 \\
19 & Physical education teacher self-assessment required & 3.177 & 1.165 \\
20 & Supervision of P.E. program delegated when appropriate & 2.785 & 1.599 \\
\hline
\end{tabular}


Table 4 shows the ranked means and corresponding standard deviations for the self-reported risk management behaviors related to the subjects' athletic program supervision practices. In a similar fashion to the principals' self-reported scores on the physical education items, the principals rated themselves rather well on the athletic-related survey items. Of the 20 athletic items, 13 had means exceeding 4.0 on the 5-point scale. Only 4 of the athletic items had means below 3.5.

Table 4. Ranked Means of Principals' Risk Management Behaviors Related to Supervision of the Athletic Program.

\begin{tabular}{llrr}
\hline Rank & Bisk Management Behavior & Mean & S.D. \\
\cline { 2 - 4 } 2 & Principal attendance at home athletic contests & 4.567 & .511 \\
2 & Adequate game security provided & 4.531 & .895 \\
3 & Objective screening process to hire coaches & 4.509 & .832 \\
4 & Coaches present at athletic practices & 4.502 & 1.013 \\
5 & Athletic director supervises program adequately & 4.498 & .900 \\
6 & Principal interaction with coaches & 4.482 & .765 \\
7 & Title IX requirements met in athletics & 4.465 & .960 \\
8 & State high school athletic association rules met & 4.460 & .985 \\
9 & School-owned or contracted vehicles used for away contests & 4.315 & 1.290 \\
10 & Identified facility hazards repaired properly & 4.299 & .888 \\
11 & Adequate salety measures exist & 4.232 & .948 \\
12 & Safe transportation is provided for away contests & 4.127 & 1.357 \\
13 & Medical emergency procedures exist & 4.105 & 1.200 \\
14 & Written criteria are used for evaluating coaches & 3.978 & 1.264 \\
15 & Coaches use professionally-accepted coaching methods & 3.975 & 1.056 \\
16 & New coaches informed of responsibilities & 3.901 & 1.247 \\
17 & Coaches attend coaching clinics & 3.489 & 1.247 \\
18 & Safety clinics are conducted for coaches & 3.173 & 1.176 \\
19 & Safety officer designated for athletics program & 2.901 & 1.643 \\
20 & Principal attendance at athletic practices & 2.859 & .834 \\
& & & \\
\hline
\end{tabular}

\section{Statistical Analyses by School Size}

One-way analyses of variance conducted by school size ( $A=$ smallest, followed by $1 \mathrm{~A}, 2 \mathrm{~A}, 3 \mathrm{~A}$, and $4 \mathrm{~A}=$ largest) upon each of the survey items revealed only one survey item with significant mean differences $(p<.05)$ among the 20 physical education program supervision items. Principals of $4 \mathrm{~A}$ schools, the largest high schools, scored significantly higher than did the principals of all the other classifications (i.e., A, I A, 2A, and 3A) on the survey item which read, "Where the principal believes that he or she lacks the expertise to supervise particular physical education teachers, he or she delegates that responsibility to someone with the appropriate knowledge."

One-way analyses of variance conducted by school size upon each of the survey items revealed five items with significant mean differences $(p<.05)$ among the 20 athletic program supervision items. Principals of A schools, the smallest high schools, scored significantly higher than did principals of $3 \mathrm{~A}$ school on the following three items: (a) "The principal determines that appropriate, safe transportation is provided for athletic events"; (b) "The principal determines that coaches use standard, professionally acceptable coaching techniques"; and (c) "The princi- 
pal determines that school-owned vehicles or privately contracted transportation services are used to transport athletes to out of town contests." Principals of A schools scored significantly higher than did principals of $1 \mathrm{~A}$ schools on the survey item which read, "The principal informs new coaches of their specific duties and responsibilities." Finally, principals of $4 \mathrm{~A}$ schools scored significantly higher than did principals of $3 \mathrm{~A}$ schools on the survey item which read, "The principal determines that safety clinics are conducted to keep coaches up to date on safety issues."

A one-way analysis of variance conducted by school size among the composite means of the 20 physical education program supervision items combined revealed no significant differences ( $>$.05). A one-way analysis of variance conducted by school size among the composite means of the 20 athletic program supervision items combined revealed no significant differences ( $p>05$ ). Finally, a one-way analysis of variance conducted by school size among the composite means of all 40 survey items combined revealed no significant differences ( $>>05)$.

\section{- SUMMARY AND CONCLUSIONS}

The purpose of this study was to determine the degree to which high schools principals indicated that they performed various risk management behaviors related to the administrative supervision of their physical education and athletic programs. According to the data collected in this study, the principals generally indicated that they were performing most of the risk management behaviors addressed by the survey items in a rather consistent manner. Of course, it must be noted that the principals' responses were self-reported assessments of their own consistency in performing these identified behaviors, and they were not scores reported by the physical education teachers, coaches, athletic directors, or others. The data revealed very few statistically significant differences based upon school size, indicating that few differences were noted among larger schools versus smaller schools. It seems that principals, at least those who chose to participate in this study, are very much aware of their legal responsibilities related to the administrative supervision of their high school physical education and athletic programs and, in addition, it seems that these principals were performing those supervisory responsibilities rather consistently. 


\section{References}

Essex, N. L. (1986, September). The principal and educational malpractice: Is there a lawsuit in your future? Principal, pp. 21-22.

Gluckman, I. B. (1985, October). Legal aspects of student activities. NASSP Bulletin, pp. 10-16.

Hager, J. L., \& Scarr, L. E. (1983, February). Effective schools-effective principals: How to develop both. Educational Leadership, pp. 38-40.

Heitmann, H. M. (1988, February). Supervising the secondary school physical education curriculum. NASSP Bulletin, pp. 86-93.

Hill, J. C.(1990, January). The principal as curriculum supervisor. Principal, pp. 6-9.

Kienapfel, B. (1984, September). Supervision of curriculum at the middle level. NASSP Bulletin, pp. 52-57.

Virgilio, S. J., \& Virgilio, I. R. (1989). The role of the principal in curriculum implementation. Education, 104(4), 346-50.

Zirkel, P. A., \& Moore, J. T. (1986, March). Playground accidents: When are you liable? Principal, pp. 43-46. 